\title{
PENILAIAN STAKEHOLDER MENGGUNAKAN MALCOLM BALDRIGE \\ DALAM PENGUATAN AMAL USAHA 'AISYIYAH
}

\author{
Roosita Meilani Dewi ${ }^{1}$, Diyah Hesti Kusumawardani ${ }^{2}$ \\ Sekolah Tinggi Ilmu Ekonomi Ahmad Dahlan Jakarta \\ Jl. Ciputat Raya N0.77 Cirendue Ciputat - Jakarta Selatan 15419
}

\begin{abstract}
The research of one of Aisyiyah's business charities aims to evaluate and provide an assessment on early childhood education namely TK Bustanul 'Athfal /' Aisyiyah. The type of this research is descriptive-quantitative with case study taking charity effort of kindergarten 'Aisyiyah under PCA Assembly of CiputatTimur with assessment method Malcolm Baldrige take third valuation point concerning about customer and market focus by measuring two dimension that is costumer-market knowledge and performance satisfaction customer. The result shows the knowledge dimension of $59,065 \%$ achievement from the maximum score on Malcolm Baldrige 40 index, while the dimension of customer satisfaction performance shows the result of $63,91667 \%$ from the maximum score of 45. This shows that the assessment about the knowledge of the customer and the market on the pupils, more stakeholders low compared to the assessment of customer satisfaction and market performance.
\end{abstract}

$\begin{array}{ll}\text { Keywords } & \text { : 'aisyiyah, stakeholder,market, pupils,satisfaction, assessment, index } \\ \text { Correspondence to } & \text { : roositamd05@gmail.com }\end{array}$

\begin{abstract}
ABSTRAK
Penelitian salah satu amal usaha 'Aisyiyah bertujuan untuk mengevaluasi dan memberikan penilaian pada pada pendidikan usia dini yaitu TK Bustanul 'Athfal/'Aisyiyah. Jenis penelitian ini adalah deskriptif-kuantitatif dengan studi kasus mengambil amal usaha TK 'Aisyiyah di bawah majelis dikdasmen PCA Ciputat Timur dengan metode penilaian Malcolm Baldrige mengambil poin penilaian ketiga mengenai tentang customer and market focusdengan mengukur dua dimensi yaitu pengetahuan costumer-pasardan performance kepuasan pelanggan. Hasil menunjukkan pada dimensi pengetahuan sebesar 59,065\% ketercapaiannya dari maksimal score pada indeks Malcolm Baldrige 40, sedangkan dimensi performance kepuasan pelanggan menunjukkan hasil $63,91667 \%$ dari score maksimal 45. Hal ini menunjukkan bahwa penilaian mengenai pengetahuan tentang customer dan pasar pada murid, stakeholder lebih rendah dibandingkan dengan penilaian mengenai performance kepuasan customer dan pasar.
\end{abstract}

Kata kunci : angka kematian ibu, determinan jarak jauh, determinan intermediate, Determinan hasil

Korespondensi : : roositamd05@gmail.com 


\section{PENDAHULUAN / INTRODUCTION}

Setiap kali Muhammadiyah dan 'Aisyiyah merayakan milad maka akan tampak gambar tentang berapa banyak amal usaha dan amal sosial yang dimiliki oleh Muhammadiyah dan 'Aisyiyah. Sebagai organisasi sektor publik, amal usaha merupakan entitas ekonomi ${ }^{1}$ yang diperlukan untuk menyediakan jasa seperti pendidikan, kesehatan untuk meningkatkan kesejahteraan masyarakat dan bukan untuk mencari keuntungan finansial2. Amal usaha juga memiliki kewajiban pertanggungjawaban yang lebih besar kepada publik atas danadana yang dimiliki.

Namun tidak semua amal usaha memberikan laporan keuangan yang dapat diakses publik, sebagai bentuk pertanggungjawaban amal usaha kepada publik. Hal ini terjadi terutama pada amal usaha yang dikelola swasta. Hal ini terjadi karena sebagian amal usaha swasta hanya dikelola secara alami (by nature) ataupun lebih merefleksikan perilaku saling percaya (mutual trust) yang seringkali mengabaikan unsur-unsur akuntabilitas dan praktek good governance, profesionalisme manajemen ${ }^{3}$. Tidak terkecuali untuk amal usaha yang memakai simbol agama Islam dalam namanya. Misalnya amal usaha Muhammadiyah dan 'Aisyiyah.

Padahal amal usaha yang memakai simbol Islam, mempunyai tanggungjawab besar tidak hanya kepada publik tetapi juga Allah Swt. Bentuk dan proses pencatatan laporan keuangan pun harus sesuai dengan

\footnotetext{
${ }^{1}$ Entitas ekonomi berarti organisasi tersebut memiliki dan mengelola sumber daya ekonomi yang tidak kecil serta melakukan transaksitransaksi ekonomi dan keuangan.

${ }^{2}$ Deddi Nordiawan, Ayuningtyas Hertianti.

"Akuntansi Sektor Publik". Salemba Empat, 2010

${ }^{3}$ Materi Good University Governance, Majelis Dikti Litbang PP Muhammadiyah
}

kaidah akuntansi islam, sebagai bentuk pertanggungjawaban atas pemakaian simbol Islam dalam nama amal usaha tersebut. Bahkan jika tidak memakai simbol Islam, jika pengelola amal usaha adalah muslim, maka wajib baginya untuk membuat laporan keuangan yang dapat dipertanggungjawabkan kepada Allah Swt sebagai bentuk ibadah.

\section{PERSPEKTIF TEORITIS}

Menurut Kotler dan Fox (1995), stakeholder amal usaha terdiri dari :peserta didik/murid baik yang aktual maupun potensial, badan akreditasi, orang tua/wali, dosen, peneliti, karyawan serta staf pimpinan, dewan penyantun, institusi sejenis, pemasok, organisasi bisnis dan publik, yayasan, alumni, masyarakat setempat dan media massa. Para stakeholder ini memiliki harapan dan persepsi yang berbeda terhadap lembaga pendidikan dalam mendukung keberadaannya.

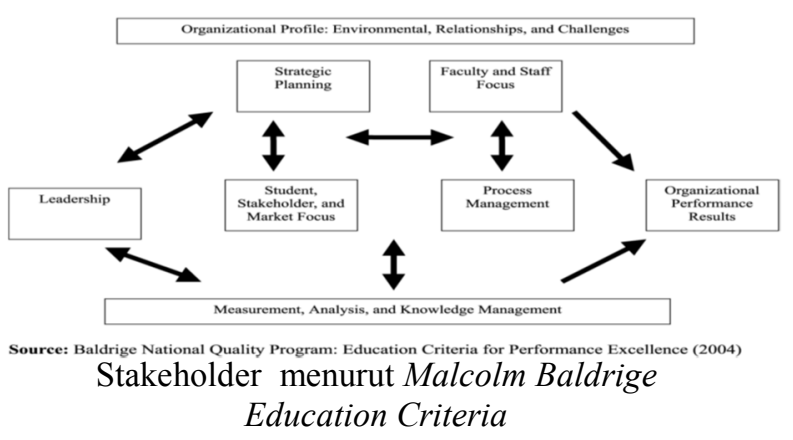

Dalam kriteria Baldrige untuk pendidikan, fokus pada pelajar/murid, stakeholder, dan pasar ialah menunjukkan bagaimana organisasi (amal usaha) mencari cara untuk memahami kebutuhan saat ini dan di masa depan dari murid dan stakeholder juga memahami pasar, dengan cara fokus pada bagaimana memuaskan murid dan stakeholder, membangun kesetiaan, dan memenuhi harapan murid dan stakeholder. Baldrige Education Criteria menekankan pentingnya masalah ini dalam "fokus pada pelanggan dan pasar" dan menggaris bawahi 
pentingnya pengembangan keahlian mendengarkan dan mempelajari respon terhadap pendapat opini dan komplain pelanggan.Untuk amal usaha, kepuasan dan ketidakpuasan murid dan stakeholder adalah informasi yang sangat penting untuk mengetahui tidak hanya pendapat murid dan stakeholder tetapi juga tindakan dan kekonsistenan dan umpan balik positif.

Daftar pertanyan yang akan dibuat didasarkan penelitian Masoon, et al., (2013)pada dua dimensi dan empat kategori yaitu:

1. Dimensi pertama adalah pengetahuan terhadap murid,stakeholder dan pasar (yang menjadi dua kategori yaitu pengetahuan terhadap murid dan pengetahuan terhadap stakeholder dan pasar).

2. Dimensi kedua hubungan amal usaha dengan murid dan pasar (yang menjadi dua kategori yaitu hubungan dengan murid dan pasar, penentuan kepuasan murid dan stakeholder).

Tabel 1.Penilaian Malcom Baldrige

\begin{tabular}{|c|c|c|}
\hline Kategori & Poi & Value \\
\hline $\begin{array}{l}\text { 1. Leadership } \\
\text { a. Organisational Leadership } \\
\text { b. Public Responsibilities and } \\
\text { Citizenship }\end{array}$ & $\begin{array}{l}85 \\
40\end{array}$ & 125 \\
\hline $\begin{array}{l}\text { 2. Strategic Plan } \\
\begin{array}{l}\text { a. Strategic Development } \\
\text { b. } \quad \text { Strategic Deployment }\end{array}\end{array}$ & $\begin{array}{l}40 \\
45\end{array}$ & 85 \\
\hline $\begin{array}{l}\text { 3. Costumer and Market Focus } \\
\begin{array}{l}\text { a. Customer and market } \\
\text { knowledge }\end{array} \\
\text { b. Customer satisfaction } \\
\text { performance }\end{array}$ & $\begin{array}{l}40 \\
45\end{array}$ & 85 \\
\hline $\begin{array}{l}\text { 4. Information and Analisis } \\
\text { a. Measurement of } \\
\text { organisational performance } \\
\text { b. Analysis of organisation } \\
\text { performance }\end{array}$ & $\begin{array}{l}40 \\
45\end{array}$ & 85 \\
\hline
\end{tabular}

Penelitian ini merupakan investigasi empiris atas pelaksanaan praktek pelaksanaan manajemen berdasarkan dimensi-dimensi dan kategori yang dikemukakan dalam Malcolm Baldridge pada amal usaha 'Asiyiyah tahun 2017. Fokus penelitian ini pada amal usaha 'Aisyiyah yaitu Sekolah TK Bustanul Athfal yang berada di wilayah binaan majelis Dikdasmen PCA (Pimpinan Cabang 'Aisyiyah) Ciputat Timur. Diharapkan jika amal usaha memiliki hasil penilaian dan kriteria yang baik dan bagus yang sesuai dengan aturan yang telah ditetapkan lembaga ('Aisyiyah) maupun dinas pendidikan setempat, akan meningkatkan penilaian stakeholder dan akhirnya meningkatkan kepercayaan stakeholder.

Penelitian"Penguatan Amal Usaha 'Aisyiyah Melalui Penilaian Stakeholder" ini diharapkan dapat mengidentifikasi masalah mengenai bagaimana praktek pelaksanaan manajemen amal usaha sekolah TK 'Aisyiyah dalam hubungannya dengan stakeholder yang berhubungan,dan melihat penilaian stakeholder terhadap amal usaha 'Aisyiyah (TK 'Aisyiyah) tersebut.

Penelitian ini mengambil sampel dari populasi amal usaha 'Aisyiyah pada tahun 2017. Setiap amal usaha akan mengambil sampel responden yang dianggap mewakili populasi stakholder amal usaha tersebut, sampel yang digunakan dalam penelitian ini dari unsur guru, wali murid, dan pegurus dengan pengambilan jumlah sample secara acak. Dari tiga sekolah yang menjadi populasi diambil 30, sehingga setiap 10 responden diambil secara proporsional atau menggunakan teknik proportionated random sampling. Daftar penilaian stakeholder diambil dari penilaian Malcolm Badlrige Education Criteria pada variabel ketiga yaitu fokus pada Murid, Stakeholder, dan Pasar.

Penelitian ini hanya mencakup amal usaha 'Aisyiyah di Ciputat Timur Tangerang Selatan. Dimana kepemimpinan 'Aisyiyah cabang Ciputat Timur baru terbentuk kurang lebih dua periode karena hasil pemekaran 
wilayah, selain itu kedekatan lokasi penelitian dengan institusi pendidikan diatasnya yang merupakan bagian dari amal usaha Muhammadiyah yaitu STIE Ahmad Dahlan dan Universitas Muhammadiyah Jakarta, dan institusi pendidikan lain yang bagus. Ciputat merupakan kota kecamatan yang cukup padat dan dinmis dengan perkembangan institusi pendidian dari tingkat tingkat pr sekolah sampai perguruan tinggi, sebagai daerah perbatasan dan cukup dekat dengan ibukota menjadikan Ciputat cukup banyak dikenal serta menjadi pilihan bermukim serta memilih pendidikan.

\section{METODE PENELITIAN / METHODS}

Penelitian ini menggunakan pendekatan diskriptif kuantitatif dengan paparan melalui pendekatan kualitatif. Pendekatan deskriptif dengan menggambarkan fakta yang terjadi dalam penelitian, sedangkan pendekatan kuantitatif yang mengacu pada angka - angka sebagai dasar analisa dan pengambilan kesimpulan, dan untuk mengukur hasil penilaian sesuai dengan standart penilaian dimensi Malcom Baldrige. Namun paparan yang kita gunakan dalam penelitian ini lebih banyak menggunakan pendekatan kualitatif, yakni penelitian yang berintikan pada proses penelitian yang memiliki setting alamiah, dimana peneliti mengkaji fenomena yang diteliti secara empiris. Pendekatankualitatif yang

digunakandalampenelitianinimenggunakanme todeCase Study (StudiKasus). Studikasus adalah mengeksplorasi "bounded system"atau sistem yang dibatasi baik yang berupa kasus tunggal atau bahkan beberapa kasus secara detail, mendalam, data yang dikumpulkanjugadaribeberapasumber yang banyaksesuaidengankonteks yang diteliti (Cres-well,1998). Yin menjelaskan secara teknis metode studi kasus adalah mempertanyakan kejadian empiris untuk menyelidiki fenomena kontemporer dalam konteks kehidupan nyata, ketika batas-batas antara fenomena dan konteks tidak terlihat jelas dan sejauh mana berbagai sumber bukti yang akan digunakan (Yin,1981).

Penelitian ini menggunakan penentuan subjek penelitian sebagai sumber data yang diharapkan mampu menjawab permasalahan dari peneliti. Adapun subjek dalam penelitian ini adalah stakeholder sekolah TK 'Aisyiyah di bawah Majelis Dikdasmen PCA Ciptim.Penelitian ini dilakukan pada amal usaha TK 'Aisyiyah di Ciputat Timur karena merupakan amal usaha 'Aisyiyah yang menjadi ujung tombak pergerakan 'Aisyiyah.

Upaya memperoleh data yang akurat dan holistik sesuai dengan fokus penelitian maka dalam penelitian ini peneliti menggunakan tiga teknik yang berbeda yakni wawancara, observasi dan dokumentasi.Data yang terkumpul dari wawancara, observasi dan dokumen dalam penelitian banyak sekali dan terdiri dari beraneka ragam. Data yang banyak tersebut tidak mungkin akan peneliti ambil seluruhnya, karena peneliti hanya akan mengambil data yang sesuai dengan arah penelitian yang dijabarkan dalam fokus penelitian. Data hasil kuesioner dari 30 orang dari unsur guru dan wali murid, dianalisis menggunakan skoring skala linkert, kemudian diolah sederhana menggunakan persentase dan hasilnya dikonversikan dengan nilai maksimal dimensi standart Malcolm Baldrige.

Oleh karena itu, diperlukan adanya analisis data yang relevan dengan rumusan masalah penelitian ini. Proses analisis data dimulai dari seluruh data yang diperoleh dari berbagai sumber, yaitu pengamatan, wawancara dan dokumentasi. Kegiatan pengolahan dan analisis data sejatinya telah dilakukan sejak awal penelitian dan selama proses penelitian berlangsung.Penarikan kesimpulan dilakukan jika pengumpulan data dianggap cukup memadai dan dianggap selesai. Jika terjadi kesimpulan yang dianggap kurang memadai 
Balance Vol. XV No. 1 | Januari 2018

maka diperlukan aktifitas verifikasi dengan sasaran yang lebih luas.

Tabel 2

Daftar pertanyaan yang akan diajukan pada murid dan stakeholder amal usaha 'Aisyiyah Fokus pada murid, stakeholder, dan pasar

( pengetahuan terhadap murid, stakeholder dan pasar -

pengetahuan terhadap murid)

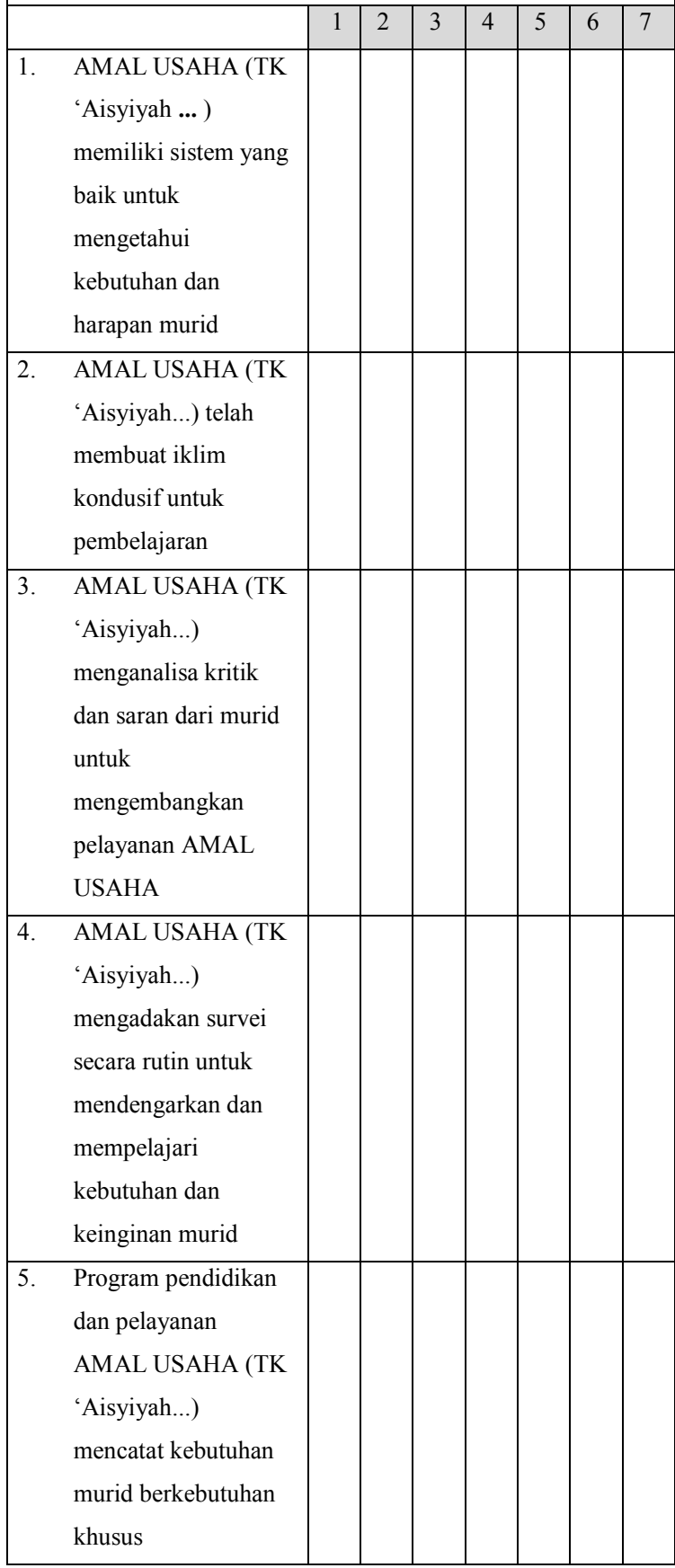

\begin{tabular}{|c|c|c|c|c|c|c|c|c|}
\hline & \multirow[t]{2}{*}{ Daftar Pertanyaan } & \multicolumn{7}{|c|}{$\begin{array}{l}\text { skala (1) tidak sama sekali, (4) } \\
\text { kadang-kadang, (7) selalu }\end{array}$} \\
\hline & & 1 & 2 & 3 & 4 & 5 & 6 & 7 \\
\hline 6. & $\begin{array}{l}\text { AMAL USAHA (TK } \\
\text { ‘Aisyiyah...) } \\
\text { memiliki unit } \\
\text { pelayanan yang } \\
\text { efektif dalam } \\
\text { penempatan murid }\end{array}$ & & & & & & & \\
\hline 7. & $\begin{array}{l}\text { AMAL USAHA (TK } \\
\text { ‘Aisyiyah...) } \\
\text { memiliki } \\
\text { ekstrakurikuler yang } \\
\text { bermacam-macam }\end{array}$ & & & & & & & \\
\hline 8. & $\begin{array}{l}\text { Program pendidikan } \\
\text { AMAL USAHA (TK } \\
\text { 'Aisyiyah...) } \\
\text { menekankan } \\
\text { pendekatan } \\
\text { penyelesaian masalah } \\
\text { (problem solving) }\end{array}$ & & & & & & & \\
\hline 9. & $\begin{array}{l}\text { Program pendidikan } \\
\text { AMAL USAHA(TK } \\
\text { 'Aisyiyah...) } \\
\text { menekankan keahlian } \\
\text { pembelajaran dan } \\
\text { berkomunikasi }\end{array}$ & & & & & & & \\
\hline 10. & $\begin{array}{l}\text { Program pendidikan } \\
\text { AMAL USAHA (TK } \\
\text { 'Aisyiyah...) } \\
\text { menekankan keahlian } \\
\text { berpikir kritis }\end{array}$ & & & & & & & \\
\hline
\end{tabular}

\begin{tabular}{|c|c|c|c|c|c|c|c|}
\hline \multicolumn{8}{|c|}{$\begin{array}{l}\text { Fokus pada murid, stakeholder, dan pasar } \\
\text { (pengetahuan terhadap murid, stakeholder dan } \\
\text { pengetahuan terhadap stakeholder, dan pasar) }\end{array}$} \\
\hline & 1 & 2 & 3 & 4 & 5 & 6 & 7 \\
\hline \multicolumn{7}{|l|}{ 11. Progam AMAL } & \\
\hline USAHA (TK & & & & & & & \\
\hline 'Aisyiyah...) & & & & & & & \\
\hline bersangkut paut dengan & & & & & & & \\
\hline kebutuhan masyarakat & & & & & & & \\
\hline 12. Program pendidikan & & & & & & & \\
\hline
\end{tabular}


Balance Vol. XV No. 1 | Januari 2018

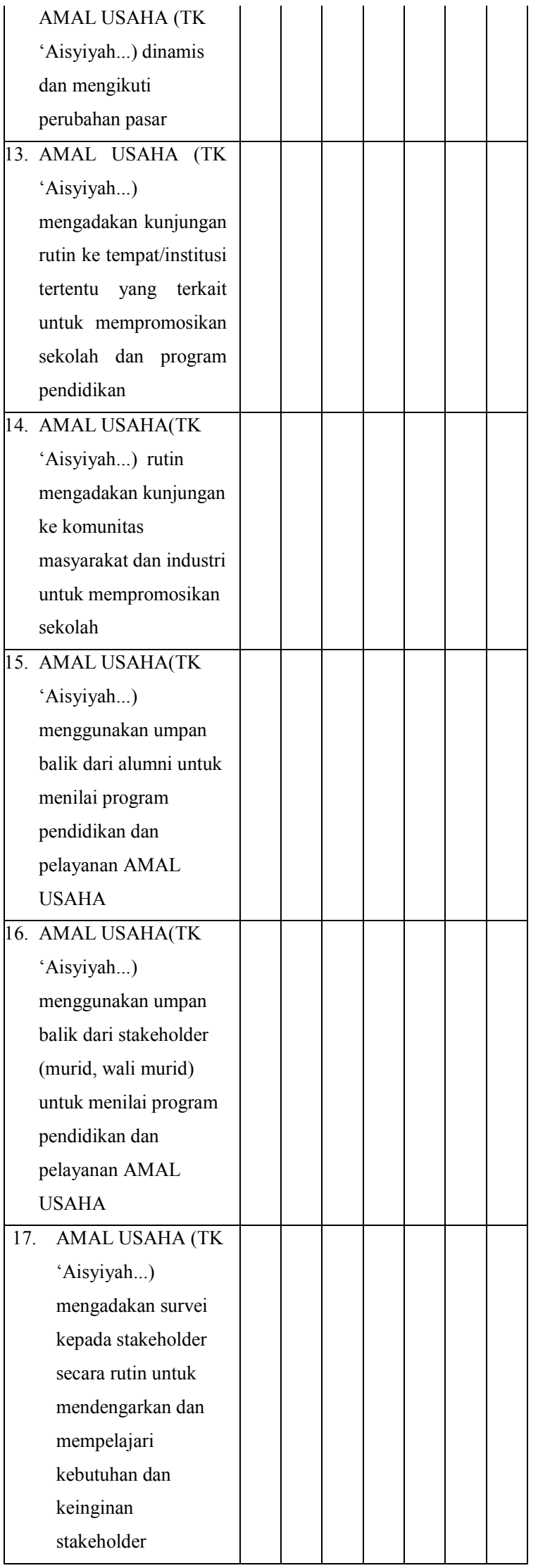

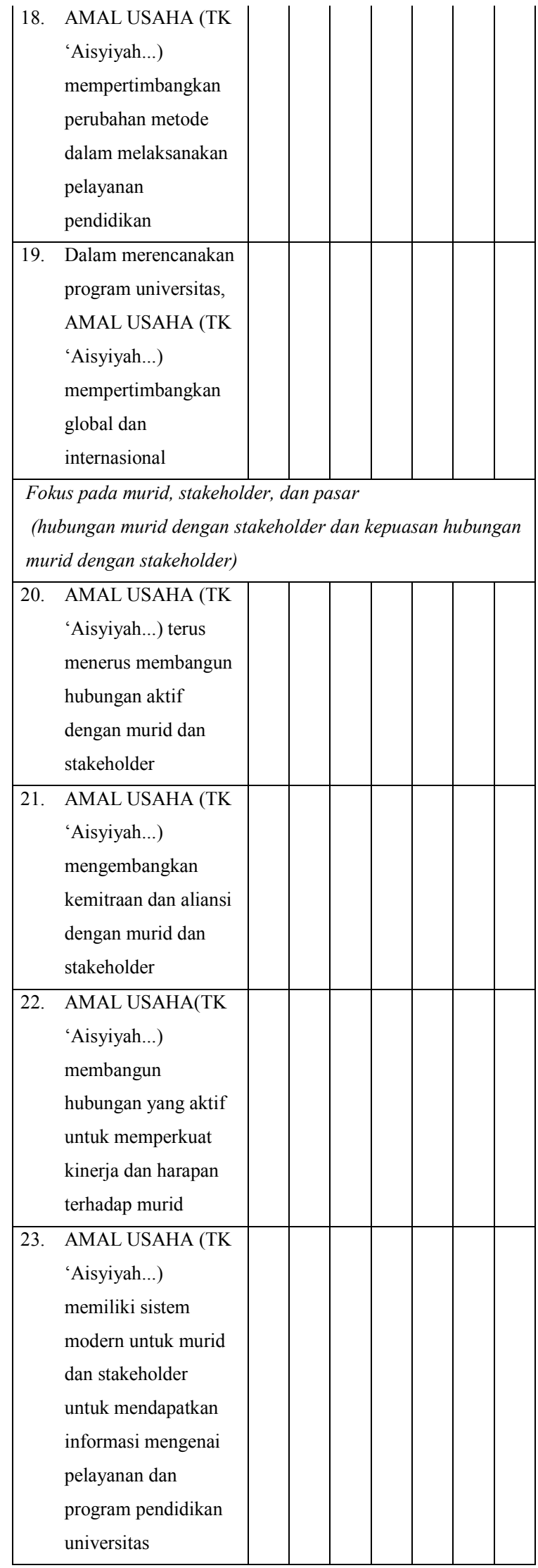


Balance Vol. XV No. 1 | Januari 2018

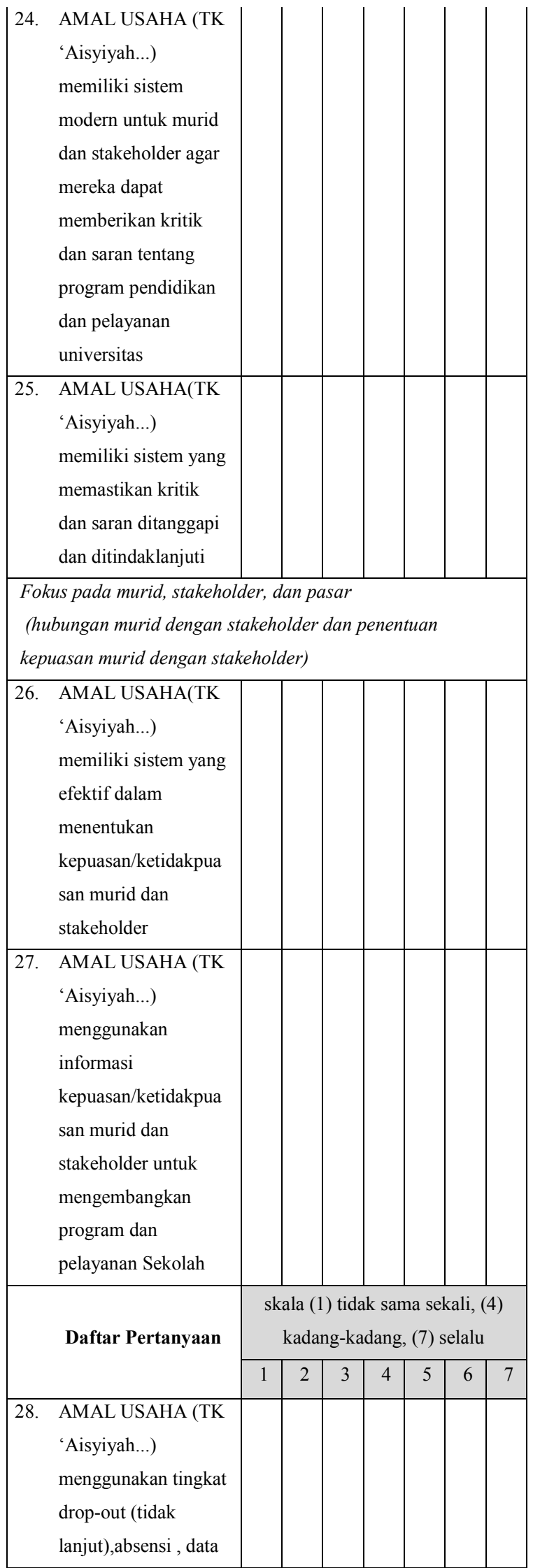

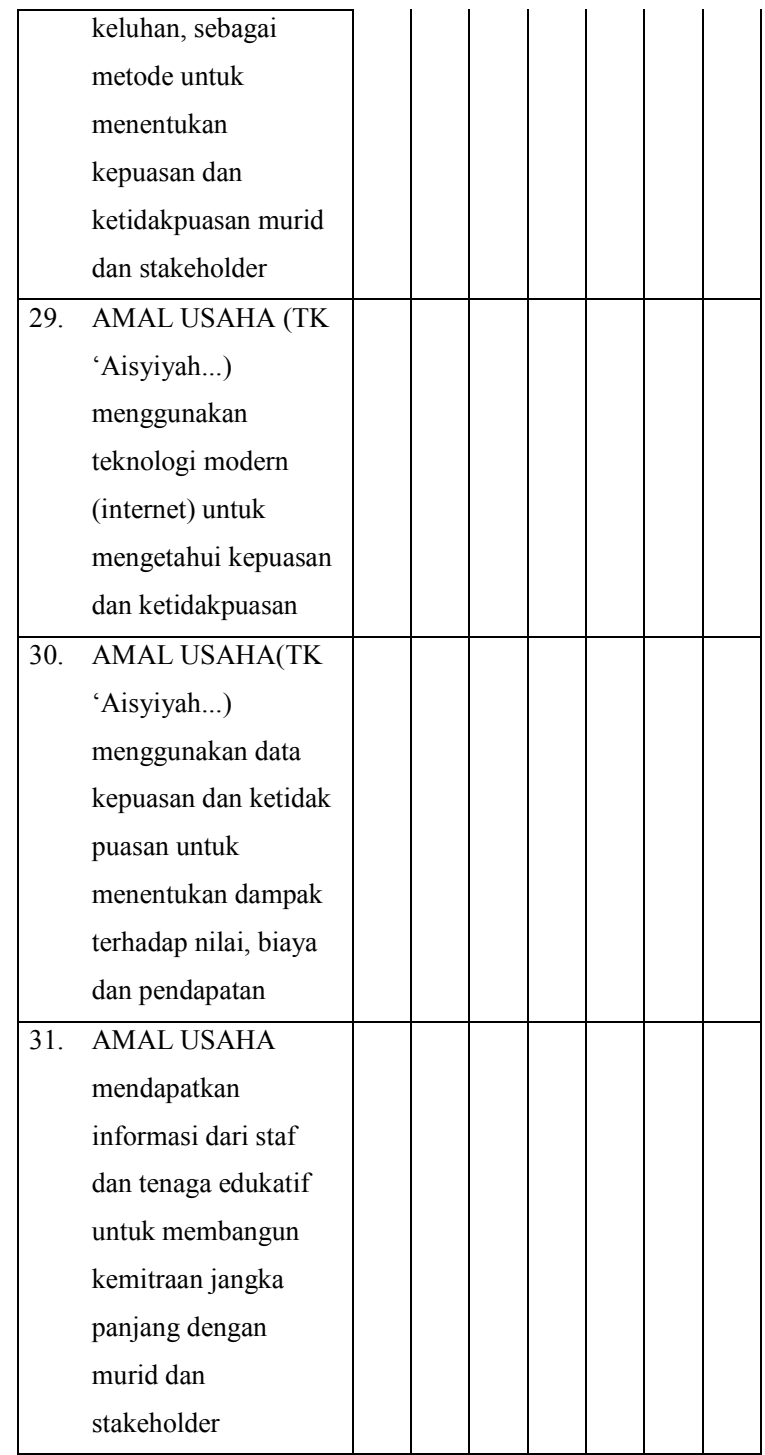

\section{HASIL DAN PEMBAHASAN Gambaran Singkat Amal Usaha 'Aisyiyah}

Amal usaha 'Aisyiyah merupakan bagian yang tak terpisahkan dari Muhammadiyah dalam perkembangannya. 'Aisyiyah adalah sebuah organisasi perempuan terbesar di dunia, ketua umum 'Aisyiyah Dra. Siti Noorjannah Djohantini, MM., M.Si.,1 memaparkan dalam Sambutan Pembukaan Seminar Pra Muktamar, Sabtu, 23 Mei 2015, di STIKES 'Aisyiyah Yogyakarta (Shobahiya.M,2015). Berkembangnya 'Aisyiyah secara organisatoris ditunjukkan dengan adanya 9.522 Ranting, 2.922 Cabang, 435 Daerah, 34 
Wilayah, dan 2 (dua) Cabang Istimewa (di luar negeri) di Malaysia dan Mesir. Sedangkan Muhammadiyah sebagai organisasi induk ada 448 Daerah, 3.566 Cabang, 13.137 Ranting, dan 15 PCIM (Pimpinan Cabang Istimewa Muhammadiyah). Amal usaha 'Aisyiyah ditunjukkan dengan dimilikinya 15.918 TK/PAUD (Taman Kanakkanak/Pendidikan Anak Usia Dini), 1.607 Satuan PAUD sejenis, 72 Taman Asuh Anak, 1.579 Taman Pendidikan Al-Qur'an, 18 SD (Sekolah Dasar), 5 (lima) MI (Madrasah Ibtidaiyah), 4 (empat) SMP (Sekolah Menengah Pertama), 8 (delapan) MTs (Madrasah Tsanawiyah), 5 (lima) SMK (Sekolah Menengah Kejuruan), 3 (tiga) SMA (Sekolah Menengah Atas), 5 (lima) MA (Madrasah Aliyah), 229 Madrasah Diniyah Awaliyah Putri, 3 (tiga) Pesantren, 4.280 Pendidikan Non Formal, 18 Sekolah Berkebutuhan Khusus, 8(delapan) PTA (Perguruan Tinggi 'Aisyiyah), 15 RS (Rumah Sakit), 64 RB (Rumah Bersalin), 7 (tujuh) RSIA (Rumah Sakit Ibu dan Anak), 27 BP (Balai Pengobatan), 44 BKIA (Balai Kesehatan Ibu dan Anak), 3 (tiga) apotik, 52 Posyandu (Pos Pelayan Terpadu), 230 panti asuhan, dan 843 koperasi ${ }^{4}$.

Berkembangnya 'Aisyiyah secara kuantitas dan kualitas menuntut sebuah manajemen dan hubungan dengan pengguna atau stakeholder amal usaha 'Aisyiyah tersebut perlu ditingkatkan secara kualitas. Penelitian ini merupakan studi kasus evaluasi amal usaha 'Aisyiyah menggunakan teori Malcom Baldrigepada Taman Kanak-Kanak (TK) di Ciputat Timur.

Tabel 3. Data hasil interview respondent

\begin{tabular}{|l|l|l|l|l|l|l|l|}
\hline $\begin{array}{l}\mathrm{N} \\
\mathrm{o}\end{array}$ & Dimensi & Kategori & $\begin{array}{l}\text { Nilai } \\
\text { Mak } \\
\mathrm{s}\end{array}$ & SC & $\begin{array}{l}\text { Total } \\
(\%)\end{array}$ & $\begin{array}{l}\text { Perbandi } \\
\text { ngan } \\
\text { Maks- } \\
\text { Real }(\%)\end{array}$ & $\begin{array}{l}\text { Capai } \\
\text { an } \\
(\%)\end{array}$ \\
\hline
\end{tabular}

${ }^{4}$ Laporan Pimpinan Pusat 'Aisyiyah Periode 2010-2015, disampaikan dalam Muktamar ke-47 Satu Abad 'Aisyiyah 3-7 Agustus 2015 M di Makassar.

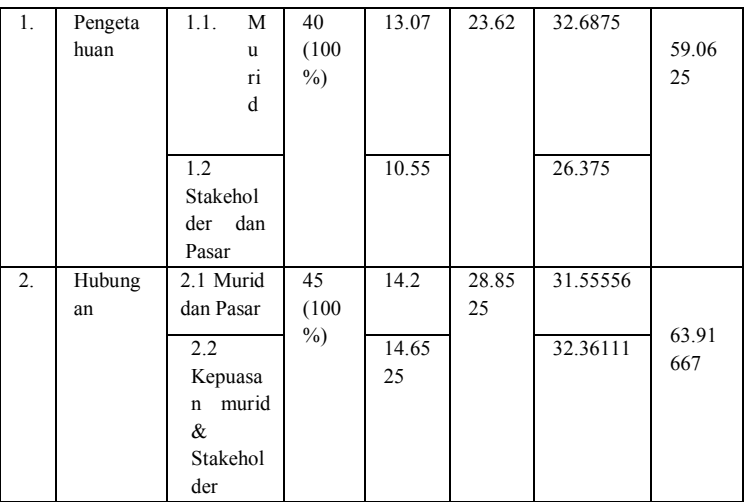

Sumber : Hasil olah data primer

Hasil wawancara dan perhitungan persentase serta perbandingan menggunakan indeks penilaian Malcolm Baldrige, maka dapat dilihat bahwa hasil yang dicapai pada dua dimensi poin 3 indeks Malcolm Baldrige yaitu Customer dan Market Focus dimensi kedua yaitu kategori hubungan murid dan pasar menunjukkan nilai yang lebih tinggi dibandingkan dimensi pertama yaitu pengetahuan murid dan pengetahuan stakeholder dan pasar. Uraian hasil penilaian sebagai berikut :

1. Dimensi pengetahuan dengan kategori murid menghasilkan score 13.07 dari score maksimal 20, hal ini menunjukkan bahwa pengetahuan stakeholder yang berhubungan dengan sistem yang efektif, iklim kondusif dalam pelayanan, analisa kritik dan saran dari murid untuk pengembangan pelayanan, survei rutin untuk mempelajari kebutuhan dan keinginan murid, dan mencatat kebutuhan murid yang berkebutuhan khusus,memeiliki unit penempatan murid yang efektif, keragaman ekstrakurikuler, pendekatan problem solving, menekankan keahlian berkomunikasi dan berpikir kritis belum optimal walaupun dari score maksimal menunjukkan ketercapaian lebih dari $50 \%$.

2. Dimensi pengetahuan dengan kategori stakeholder dan pasar menunjukkan hasil score 10.55, artinya kategori ini lebih 
rendah ketercapaiannya yang ada sangkut pautnya dengan kebutuhan masyarakat, dinamisasi dan mengikuti perubahan pasar, kunjungan rutin ke institusi atau komunitas untuk promosi sekolah, penggunaan umpan balik alumni dan wali murid untuk menilai program, mengadakan survei secara rutin dan merencanakan program secara nasional dan internasional.

Dimensi pengetahuan menunjukkan ketercapaian 59.0625\% dari penetapan indeks Malcolm Balrige, hal ini merupakan hal yang memperlihatkan bahwa pengetahuan mengenai murid, stakeholder dan pasar belum mencapai nilai maksimal walupun sudah diatas $50 \%$.

Beberapa hal yang menyebabkan ketidakoptimalan hasil penilaian pada dimensi pengetahuan, karena tidak adanya sistem baku secara Nasional untuk sekolah TK dan PAUD dari Pimpinan Pusat 'Aisyiyah. Jikapun ada peraturanperaturan Majelis Dikdasmen PP 'Aisyiyah merupakan aturan lama yang belum disesuaikan dengan perkembangan dunia pendidikan saat ini. Bahkan beberpa sekolah TK 'Aisyiyah belum mengetahuinya, artinya belum ada sosialisasi secara masif pada sekolahsekolah 'Aisyiyah. Standart operasional, muatan, dan sistem yang baku perlu dibuat dan menjadi pedoman secara menyeluruh bagi semua sekolah TK -PAUD di Indonesia.

3. Dimensi hubungan dengan kategori kepuasan hubungan murid dengan stakeholder dengan hasil 14,2 dari maksimal score 20, hal ini mencerminkan penilaian atau evaluasibahwa amal usaha terus -menerus membangun hubungan aktif dengan murid dan stakeholder untuk memperkuat kinerja dan harapan terhadap murid, amal usaha mengembangkan kemitraan dan aliansi dengan murid dan stakeholder, adanya sistem modern untuk murid dan stakholder, memiliki sistem modern dalam memberikan saran dan kritik sehingga memastikan ditanggapi/ ditindaklanjuti.

4. Dimensi hubungan murid dan stakeholder dan penentuan kepuasan murid dengan stakeholder menghasilkan penilaian yang paling tinggi dibandingkan dengan kategori yang lain, yaitu 14,6525 artinya pada poin ini murid dan stakeholder cukup mendapatkan pelayanan dan kepuasan. Kategori ini mengukur dan megevaluasi mengenai adanya sistem yang efektif pada amal usaha dalam menentukan kepuasan/ketidakpuaan murid dan stakholder, serta sekolah (amal usaha) telah menggunakan infomasi kepuasan/ ketidakpuasan murid dan stakeholder untuk pengembangan program dan pelayanan sekolah. Amal usaha menggunakan tingkat Drop Out, absensi, keluhan dalam menentukan kebuasan/ketidakpuasan, sekolah (amal usaha) menggunakan teknologi internet untuk mengentahui kepuasan /ketidakpuasan. Penggunaan data kepuasan/ketidakpuasan untuk menentukan dampak terhadap nilai biaya dan pendapatan, serta menerima dan menggunakan informasi dari staff dan tenaga edukatif untukmembangun kemitraaan jangka panjang dengan murid dan stakeholder. Artinya pada dimensi hubungan dan kepuasan stakeholder TK 'Aisyiyah telah berperan cukup baik, respon pasar mengenai hal tersebut juga cukup baik. Bahkan hal ini didukung dengan ikatan emosional dan ikatan organisasi sebagai warga Muhammadiyah, selain itu pelayanan serta pengabdian untuk umat dengan ugkapan KH. Ahmad Dahlan yang menjadi tagline di setiap amal usaha yaitu "hidup-hidupilah Muhammadiyah/'Aisyiyah" menjadi 
jargon bahkan spirit pengabdian tersebut terus tumbuh dan ada di setiap orang yang bekerja pada amal usaha Muhammadiyah/'Aisyiyah. Nilai-nilai Keislaman dan kemuhammadiyahan

\section{KESIMPULAN / CONCLUSSION}

\section{A. KESIMPULAN}

1. Nilai dari dimensi hubungan murid dan pasar maupun kepuasan murid dan stakeholder menunjukkan hasil yang lebih besar dibandingkan dengan nilai dari dimensi pengetahuan murid, stakeholder dan pasar. Yaitu dimensi hubungan menghasilkan $\quad 63.91667 \% \quad$ dan dimensi pengetahuan menghasilkan nilai $59.0625 \%$.

2. Dimensi hubungan dan kepuasan stakeholder TK 'Aisyiyah telah berperan cukup baik, respon pasar mengenai hal tersebut juga cukup baik. Bahkan hal ini didukung dengan ikatan emosional dan ikatan organisasi sebagai warga 'Aisyiyah dan Muhammadiyah.

B. SARAN

1. Diperlukan analisa menyeluruh semua dimensi dalam Malcolm Baldrige, untuk mendapatkan hasil evaluasi pada sebuah amal usaha sehingga menunjukkan hasil yang optimal.

2. Diperlukan perluasan populasi dalam amal usaha dan tambahan data mengenai laporan periodik baik administratif maupun keuangan, sehingga akan menghasilkan evaluasi yang komprehensif dan lebih luas kemanfaatannya. menjadi sesuatu yang melekat dan tercermin pada setiap orang yang mengabdi pada amal usaha Muhammadiyah/'Aisyiyah.

\section{DAFTAR PUSTAKA/REFERENCE}

Abdulla. M.,et al, 2006, The Baldrige Education Criteria for Performance Excellence Framework, Empirical test and validation,International Journal Quality and reliability Management: Vol. 23 No. 9, pp. 1118-1157.

Andik Dwi Saputro, 2010, Penguatan Sharia Governance melalui reformasi akuntansi. Simposium Nasional Akuntansi.

Baldrige National Quality Program, 2010, Education Criteria for Performance Exellence, National Institute of Standards and Technology in Gaithersburg, MD.

Creswell, J. W., 1998, Qualitative inquiry and research design choosing among five tradition, London:Sage..

Demetrius.K, Karathanos .P, 2005, Applying the Balanced Scorecard to Education, Journal of Education for Business Heldreff Publication, pp. 222-230.

Materi Good University Governance, Majelis Dikti Litbang PP Muhammadiyah

Nordiawan.D dan Hertianti.A, 2010. Akuntansi Sektor Publik. Salemba Empat, Jakarta

Nurhayati.S dan Wasilah,2009,Akuntansi Syariah di Indonesia

Yin, R. K. Case study research: Design and methods. London: Sage.1981.

2015. Laporan Pimpinan Pusat 'Aisyiyah Periode 2010-2015, disampaikan dalam Muktamar ke-47 Satu Abad 'Aisyiyah 3-7 Agustus 2015 M di Makassar.

2015. Program Nasional 'Aisyiyah Periode 2015-2020, disampaikan dalam Muktamar ke-47 Satu Abad 'Aisyiyah, 3-7 Agustus 2015 M, di 